It is funded by assessed contributions from its 26 members and by voluntary contributions from member and non-member countries, international organizations and other sources.

Members. American Samoa, Australia, Cook Islands, Fiji, France, French Polynesia, Guam, Kiribati, Marshall Islands, Federated States of Micronesia, Nauru, New Caledonia, New Zealand, Niue, Northern Mariana Islands, Palau, Papua New Guinea, Pitcairn Islands, Samoa, Solomon Islands, Tokelau, Tonga, Tuvalu, USA, Vanuatu, and Wallis and Futuna.

Functions. The SPC has three main areas of work: land resources, marine resources and social resources. It conducts research and provides technical assistance and training in these areas to member Pacific Island countries and territories of the Pacific.

Organization. The Conference of the Pacific Community is the governing body of the Community. Its key focus is to appoint the Director-General, to consider major national or regional policy issues and to note changes to the Financial and Staff Regulations approved by the CRGA, the Committee of Representatives of Governments and Administrations. It meets every two years. The CRGA meets once a year and is the principal decision-making organ of the Community. There are also regional offices in Fiji and Micronesia.

Headquarters: 95 Promenade Roger Laroque, BP D5,

98848 Nouméa Cedex, New Caledonia.

Website: http://www.spc.int

Email:spc@spc.int

Director-General: Dr Colin Tukuitonga (New Zealand).

\section{Shanghai Cooperation Organisation (SCO)}

Origin and Aims. The Shanghai Cooperation Organisation was founded in June 2001, having evolved out of the Shanghai Five grouping formed in 1996. All member states come from the Eurasia region.

Its principal aims are to promote closer defence, economic and cultural co-operation between member states and to 'strengthen mutual confidence and good neighbourly relations'.

Organization. The SCO's highest decision-making organ is the Heads of State Council, which meets once a year, as does a Heads of Government Council. There are also regular meetings of member states' foreign ministers and other government officials. In addition, there are two permanent bodies-a Secretariat based in Beijing, China and a Regional Counter-Terrorism Structure in Tashkent, Uzbekistan. The SCO has observer status at the UN General Assembly.

Membership. As of Feb. 2017 there were six permanent members: China, Kazakhstan, Kyrgyzstan, Russia, Tajikistan and Uzbekistan. There are also six observer states (Afghanistan, Belarus, India, Iran, Mongolia and Pakistan) and six dialogue partners (Armenia, Azerbaijan, Cambodia, Nepal, Sri Lanka and Turkey). At the SCO annual summit in Sept. 2014 a framework was put in place for admitting new members. India, Pakistan and Iran have requested full membership, with India and Pakistan scheduled to become full members during 2017. The SCO would then comprise member states accounting for over $40 \%$ of the world's population.

Headquarters: 7 Ritan Road, Chaoyang District, Beijing 100600, China.

Secretary-General: Rashid Alimov (Tajikistan).

\section{South Asian Association for Regional Co-operation (SAARC)}

SAARC was established to accelerate the process of economic and social development in member states. The foreign ministers of the seven member countries met for the first time in New Delhi in Aug. 1983 and adopted the Declaration on South Asian Regional Co-operation whereby an Integrated Programme of Action (IPA) was launched. The charter establishing SAARC was adopted at the first summit meeting in Dhaka in Dec. 1985.

Members. Afghanistan, Bangladesh, Bhutan, India, Maldives, Nepal, Pakistan, Sri Lanka. Observers. Australia, China, EU, Iran, Japan, South Korea, Mauritius, Myanmar, USA.

Objectives. To promote the welfare of the peoples of South Asia; to accelerate economic growth, social progress and cultural development; to promote and strengthen collective self-reliance among members; to promote active collaboration and mutual assistance in the economic, social, cultural, technical and scientific fields; to strengthen co-operation with other developing countries and among themselves. Agreed areas of co-operation under the Integrated Programme of Action (IPA) include agriculture and rural development; human resource development; environment, meteorology and forestry; science and technology; transport and communications; energy; and social development.

A SAARC Preferential Trading Arrangement (SAPTA) designed to reduce trade tariffs between SAARC member states was signed in April 1993, entering into force in Dec. 1995. In 1998 at the Tenth Summit in Colombo, the importance of achieving a South Asian Free Trade Area (SAFTA) as mandated by the Malé Summit in 1997 was reiterated and it was decided to set up a Committee of Experts to work on drafting a comprehensive treaty regime for creating a free trade area. The Colombo Summit agreed that the text of this regulatory framework would be finalized by 2001 .

Organization. The highest authority of the Association rests with the heads of state or government, who meet annually at Summit level. The Council of Foreign Ministers, which meets twice a year, formulates policy, reviews progress and decides on new areas of co-operation. The Council is supported by a Standing Committee of Foreign Secretaries, by the Programming Committee and by 11 Technical Committees which are responsible for individual areas of SAARC's activities. There is a secretariat in Kathmandu, headed by a Secretary-General, who is assisted in his work by seven Directors, appointed by the Secretary-General upon nomination by member states for a period of three years which may in special circumstances be extended.

Official language: English.

Headquarters: PO Box 4222, Kathmandu, Nepal.

Website: http://www.saarc-sec.org

Secretary-General: Arjun Bahadur Thapa (Nepal).

\section{Arab Fund for Economic and Social Development (AFESD)}

Established in 1968, the Fund commenced operations in 1974.

Functions. AFESD is an Arab regional financial institution that assists the economic and social development of Arab countries through: financing development projects, with preference given to overall Arab development and to joint Arab projects; encouraging the investment of private and public funds in Arab projects; and 